\section{ONCOLYTIC ADENOVIRUS EXPRESSING 4-1BBL DEMONSTRATES A SIGNIFICANT INCREASE OF SURVIVAL IN DIFFUSE MIDLINE GLIOMA MODELS}

${ }^{1}$ Virginia Laspidea*, ${ }^{1}$ Sara Labiano, ${ }^{1}$ Iker Ausejo-Mauleon, ${ }^{1}$ Daniel de la Nava ${ }^{1}$ Marc García-Moure, ${ }^{1} J a v i e r$ Marco-Sanz, ${ }^{2} J u a n$ Fueyo, ${ }^{2}$ Candelaria Gomez-Manzano ${ }^{1}$ Ana Patiño-García, ${ }^{1}$ Marta Alonso. ${ }^{1}$ Clínica Universidad de Navarra, Pamplona, Spain; ${ }^{2} M D$ Anderson Cancer Center, Houston, TX, United States

Background Diffuse Midline Gliomas (DMG) are aggressive pediatric brain tumors that arise in the brainstem of children between 5-10 years old. DMGs are the leading cause of pediatric death caused by a brain tumor, with a median survival of only 9 months. ${ }^{12}$ We have previously shown that the administration of the oncolytic adenovirus Delta-24-RGD is safe and lead to an increase in long-term survivors in murine models. ${ }^{3}{ }^{4}$ In order to further increase the antitumor effect of Delta-24-RGD by boosting the immune response, we have constructed a new adenovirus, Delta-24-ACT, which incorporates the $4-1 \mathrm{BBL}(\mathrm{CD} 137 \mathrm{~L})$ into its backbone. $4-1 \mathrm{BB}$ is a costimulatory receptor that promotes the survival and expansion of activated $\mathrm{T}$ cells and $\mathrm{NK}$ cells and the generation and maintenance of memory $\mathrm{CD} 8+\mathrm{T}$ cells, among other functions. $^{5} 6$

Methods Murine and human DMG cell lines were used. 4$1 \mathrm{BBL}$ expression was assessed in infected cells by flow cytometry and immunofluorescence. Viral protein expression was measured by western blot, viral replication was analyzed using a method based on hexon detection and the oncolytic effect by MTS assay. For in vivo experiments, cells were injected in the pons of mice using a screw-guided system. ${ }^{7}$ A single administration of the adenovirus was injected intratumorally using the same procedure. The tumor immune populations were analyzed by flow cytometry.

Results We first confirmed by flow cytometry that DMG cells infected with Delta-24-ACT expressed 4-1BBL in their membrane in a dose-dependent manner. Afterwards, we analyzed the oncolytic effect of Delta-24-ACT in vitro. Delta-24-ACT was able to express viral early and late proteins in murine and human DMG cell lines and to replicate efficiently in human cells. In addition, the virus caused cell death in a dose-dependent manner. In vivo, Delta-24-ACT administration demonstrated to be safe and to produce a significant survival benefit in murine DMG models, obtaining 30-50\% of longterm survivors depending on the model. More importantly, Delta-24-ACT generated immune memory, as long-term survivors were disease-free after cell rechallenge. On the other hand, we analyzed immune infiltration 7 or 10 days after the viral administration into the tumor and observed a significant increase of tumor infiltration in treated mice, which showed an activated state.

Conclusions Delta-24-ACT administration into DMG murine tumor models significantly increases the recruitment and activation of immune cells, which leads to long term survivors and immunological memory.

\section{REFERENCES}

1. Cooney $T$, Lane A, Bartels U, Bouffet E, Goldman S, Leary S, Foreman NK, Packer RJ, Broniscer A, Minturn JE, Shih C, Chintagumpala M, Hassall T, Gottardo NG, Dholaria H, Hoffman L, Chaney B, Baugh J, Doughman R, Leach JL, Jones BV, Fouladi M, Warren KE, Monje M. Contemporary survival endpoints: an International diffuse Intrinsic pontine glioma registry study. Neuro Oncol 2017;19 (9):1279-1280.

2. Grasso CS, Tang Y, Truffaux N, Berlow NE, Liu L, Debily MA, Quist MJ, Davis LE, Huang EC, Woo PJ, Ponnuswami A, Chen S, Johung TB, Sun W, Kogiso M, Du Y, Qi L, Huang Y, Hütt-Cabezas M, Warren KE, Le Dret L, Meltzer PS, Mao H, Quezado M, van Vuurden DG, Abraham J, Fouladi M, Svalina MN, Wang N,
Hawkins C, Nazarian J, Alonso MM, Raabe EH, Hulleman E, Spellman PT, Li XN, Keller C, Pal R, Grill J, Monje M. Functionally defined therapeutic targets in diffuse intrinsic pontine glioma. Nat Med 2015;21(6):555-9.

3. Martínez-Vélez N, Garcia-Moure M, Marigil M, González-Huarriz M, Puigdelloses M, Gallego Pérez-Larraya J, Zalacaín M, Marrodán L, Varela-Guruceaga M, Laspidea V, Aristu JJ, Ramos LI, Tejada-Solís S, Díez-Valle R, Jones C, Mackay A, Martínez-Climent JA, García-Barchino MJ, Raabe E, Monje M, Becher OJ, Junier MP, El-Habr EA, Chneiweiss H, Aldave G, Jiang H, Fueyo J, Patiño-García A, GomezManzano C, Alonso MM. The oncolytic virus Delta-24-RGD elicits an antitumor effect in pediatric glioma and DIPG mouse models. Nat Commun 2019;10 (1):2235.

4. Garcia-Moure M, Gonzalez-Huarriz M, Labiano S, Guruceaga E, Bandres E, Zalacain M, Marrodan L, de Andrea C, Villalba M, Martinez-Velez N, Laspidea V Puigdelloses M, Gallego Perez-Larraya J, Iñigo-Marco I, Stripecke R, Chan JA, Raabe EH, Kool M, Gomez-Manzano C, Fueyo J, Patiño-García A, Alonso MM. Delta-24-RGD, an oncolytic adenovirus, increases survival and promotes proinflamatory immune landscape remodeling in models of AT/RT and CNS-PNET. Clin Cancer Res 2021;27(6):1807-1820.

5. Chester C, Sanmamed MF, Wang J, Melero I. Immunotherapy targeting 4-1BB: mechanistic rationale, clinical results, and future strategies. Blood 2018;131 (1):49-57.

6. Yonezawa A, Dutt S, Chester C, Kim J, Kohrt HE. Boosting cancer immunotherapy with anti-CD137 antibody therapy. Clin Cancer Res 2015;21(14):3113-20.

7. Marigil M, Martinez-Velez N, Domínguez PD, Idoate MA, Xipell E, Patiño-García A, Gonzalez-Huarriz M, García-Moure M, Junier MP, Chneiweiss H, El-Habr E, Diez-Valle R, Tejada-Solís S, Alonso MM. Development of a DIPG orthotopic model in mice using an implantable guide-screw system. PLoS One 2017;12(1): e0170501.

http://dx.doi.org/10.1136/jitc-2021-SITC2021.745 